\title{
Soil properties and physiographic factors controlling the natural vegetation re- growth in a disturbed catchment of the Central Spanish Pyrenees
}

\author{
Ana Navas, Javier Machín, Santiago Beguería, Manuel López-Vicente, Leticia Gaspar
}

\begin{abstract}
Large changes in land use have occurred in the Central Spanish Pyrenees during the twentieth century. This mountain area supported an intense human use since the Middle Ages, that greatly transformed the natural landscape. The land uses changed dramatically during the first half of the twentieth century, due to major socioeconomic forces which lead to depopulation and land abandonment. Since then, a process of natural vegetation recovery has taken place. The anthropogenic impact during centuries deteriorated the soil quality, threatening the sustainability of agroecosystems and the natural vegetation re-growth. In this study, a soil survey was performed to identify the soil types and the physico-chemical properties of the soil that are relevant for maintaining the soil function for the recovery of vegetation after land abandonment. The study was conducted in the Arnás River catchment, which is representative of the region. The highest cation exchange capacity (CEC), nutrients, water retention, water availability and infiltration rates, as well as the lowest $\mathrm{pH}$ and carbonates, occurred in Lithic Hapludolls and Calcic Haploxerolls at the shady aspect, under a forest cover. Lithic Ustochrepts and Lithic Xerorthents on the sunny aspect, which were covered by shrubs, were of lesser quality than were the deeper and better-developed soils on the shady aspect. This is seen as an evidence of different patterns of soil degradation, which conditioned the re-growth of natural vegetation after land abandonment. The results provide insights into the main soil factors that have affected the re-establishment of natural vegetation in recent years. Recommendations are given for designing effective strategies for soil conservation after land abandonment in similar mountain environments.
\end{abstract}

\section{Keywords}

Vegetation cover - Natural re-growth - Soil properties - Physiographic factors - GIS - Central Pyrenees - Spain

\section{Introduction}

In many parts of the Mediterranean eco-region the abandonment of marginal lands after intensive soil use is a main environmental issue. Unsuitable land uses during the preindustrial era were often the cause of soil changes that led to the unsustainability of the agroecosystems. The concept of soil quality, i.e. the capacity of the soil to function, has emerged in the last decade (e.g. Karlen et al. 1997). The effect of human land use and management on the soil functions is termed the dynamic soil quality (Seybold et al. 1999). It is widely accepted that there is a need for establishing adequate soil management practices for mantaining the soil quality and thus guaranteeing the sustainability of the agroecosystems (Machín and Navas 1995). However, although soil quality is necessary for environmental 
sustainability (e.g. Webb et al. 2000), there is no universal standard of soil quality applicable to mountain environments (e.g. Burger and Kilting 1998).

The Mediterranean region is under threat from desertification because of soil loss and degradation (De la Rosa et al. 1996). Deforestation and subsequent land cultivation led to the deterioration of the soil properties as well as to increases in surface runoff and erosion (Lu et al. 2002; Sparling et al. 1994). Land use trends during the past century were towards intensification in the most productive areas, and land abandonment of the most marginal lands, such as in the mountain areas (Garcia-Ruiz and Lasanta 1990). This process is very likely to continue in the future promoted by the EU Agricultural Policy which encourages abandonment of marginal and less productive lands. Experience shows that land abandonment in the mountain areas has promoted the recovery of the natural vegetation, which is beneficial as a means of preventing desertification (Sanchez-Marañón et al. 2002). However, vegetation recovery in abandoned areas has been very irregular. Therefore, it is of interest to know the factors that control this process in order to prevent further soil degradation and improve the soil quality.

In the central part of the Spanish Pyrenees, intensive agriculture, overgrazing by livestock, and deforestation have led to severe soil degradation, and land abandonment has led to increased runoff and soil erosion (e.g. Navas et al. 1997; Beguería et al. 2003; García-Ruiz et al. 2005). As a result, in recent decades, the Pyrenean landscape has changed significantly. In general, soil degradation in areas of intensive or changing land use is relatively well-studied, although there are few studies from the temperate-zone mountain of the Mediterranean region.

Within the central Pyrenean region, the Borau Valley was one of the most strongly affected by rapid changes in land use. Since the Middle Ages, the area has been used for intensive agriculture and, since the first half of the twentieth century, land abandonment has occurred rapidly during the 50s. Fourty per cent of the area of the Borau Valley was abandoned during the twentieth century, which led to an increase in the amount of scrub vegetation (Vicente Serrano et al. 2000). Previous studies in the Borau Valley indicated that forest and shrub covered slopes that have different aspects differ in their rates of soil erosion (Navas et al. 2005a). Furthermore, the re-growth of natural vegetation in the area varied from poor on SWfacing slopes to adequate and even very good on NE-facing slopes (Molinillo et al. 1997).

The objective of this study was to assess the effect of certain soil properties relevant to the maintenance of soil functions on the natural vegetation re-growth after land abandonment on slopes with contrasting topographic characteristics. To determine the factors responsible for the differential recovery of the vegetation, a soil survey was carried out in the Arnás River catchment which is representative of this mountain region in the Borau Valley. Information on soil properties might help to identify the physiographic and edaphic factors that control the reestablishment of vegetation and to assess soil resilience (Carter and Ciolkosz 1991). We used a raster-based Geographic Information System (GIS) to integrate the soil database and map the spatial distribution of the main physico-chemical soil properties. GIS techniques have become a widely used methodology for the analysis of the spatial distribution of soil properties (Burrough 1986; Berry 1987; Rogowski 1996; Egli et al. 2006a, b). In that way, scientific criteria might be derived to determine whether there is a need to implement soil protection measures before land abandonment based on the slope physiography in temperate Mediterranean mountains. 


\section{Materials and methods}

The study area (284 ha) is located in the central part of the Spanish Pyrenees, which is a temperate mountain environment that has a sub-Mediterranean climate (Fig. 1). The catchment was selected because the entire area is underlain by Eocene marls and sandstones. The homogeneity of the parent materials facilitates distinguishing the role played by slope aspect and topography on the soil quality. The mineralogical composition of similar bedrocks in a nearby location revealed that calcite is the main component (64\%), with lesser amounts of quartz (19\%), clays (9\%), feldspars (5\%) and oxides (Pardini et al. 1991). The soil mineralogy highlights the mineralogical changes relative to the parent materials, with significant increases in clays (27-41\%) and decreases in calcite (33-44\%). Both of those components dominate the soil mineralogy and the other minerals are in the same proportions as in the bedrock.

The Arnás River divides the catchment into two distinctive physiographic areas. The left-hand side of the catchment (34\% of the catchment surface) has a main SW aspect and predominant slope gradients ranging between 30 and $40 \%$. The right-hand side $(66 \%$ of the catchment surface), on the contrary, has a NE aspect and predominant slope gradients between 10 and $20 \%$. The elevation ranges between 910 and $1,341 \mathrm{~m}$ a.s.l. The geomorphic processes on both sides had led to a variety of slope profiles, with convex forms predominating on the southwest-facing side.

Despite the homogeneity of the bedrocks, six soil types are developed on the marls and sands of the Flysch formation (US Soil Taxonomy and FAO 1989) (Fig. 1). On the left bank side of the Arnás River (34\% of the catchment), Lithic Ustochrepts (Rendsic Leptosols) and Lithic Xerorthents (Calcaric Regosols) predominate on steep southwest-facing slopes. They are shallow and poorly developed soils on unconsolidated materials. On the right bank side (66\% of the catchment), the soils on the gentler northeast-facing slopes are Calcic Haploxerolls (Haplic Kastanozems) and Lithic Hapludolls (Haplic Phaeozems). Calcic Haploxerolls have an A mollic horizon and can have a cambic horizon without lithic contact. Lithic Hapludolls have an A mollic horizon, but they do not exhibit calcic epipedon. Those brown soils are deeper $(50$ to $>75 \mathrm{~cm}$ ) and better developed than are the Lithic Ustochrepts and Lithic Xerorthents on the SW-facing slopes, which do not show clearly differentiated soil horizons.

The climate is of sub-Mediterranean type with an oceanic influence. The mean annual temperature is around $10^{\circ} \mathrm{C}$ and the mean annual rainfall of $930 \mathrm{~mm}$ presents a Mediterranean regime with peaks in autumn and spring and high inter-annual variability. However, the influence of the mountain relief moderates these conditions with respect to a typical Mediterranean climate. Snowfall is frequent in winter, and storms are quite common in summer.

Soil movement is very active in some areas of the catchment, mainly on the steep SW-facing slopes, in which some slumps occur (Lorente et al. 2000). Overland flow affects the bare surfaces that are frequent on those slopes and as a consequence rills are also abundant. On the NE-facing slopes, there is a system of gullies that evacuate the overland flow towards the Arnás River throughout most of the year (García-Ruiz et al. 2005). 
Soil erosion is severe in some parts of the catchment. Erosion rates were estimated using ${ }^{137} \mathrm{Cs}$ measurements recorded along transects (Navas et al. 2005a). The highest soil losses occurred on the SW-facing slopes where bare surfaces were abundant. In contrast, soil stability was predominant on the NE-facing slopes were erosion was almost negligible. Along the river valley from the head to the outlet of the catchment both erosion and deposition occurred but rates were lower than on the SW-facing slopes.

The current vegetation is composed of sub-Mediterranean shrubs (Buxus sempervirens, Genista scorpius, Echinospartum horridum and Juniperus communis) on the SW-facing slopes (SWS: SW shrub covered slope), with some bare soil and areas of open "matorral" (Mediterranean scrubland). A much denser vegetation of pine (Pinus silvestris) and deciduous trees (Quercus faginea, Populus tremula and Populus nigra) is found on the NEfacing slopes (NEF: NE forest covered slope).

According to the existing literature, the potential vegetation in the Pyrenees follows an altitudinal pattern slightly modified by the slope exposure. In the study area, it corresponds to the oak domain ("quejigal"), dominated by a forest of $Q$. faginea, on both the North and South facing slopes. Despite of having the same potential vegetation, there were differences between both exposures, the $\mathrm{N}$ slopes being more densely covered and having a higher diversity of species (Villar et al. 2001). After the human disturbance, the climax oak forest was typically substituted by pine trees (Pinus sylvestris). These serial pine forests will evolve into mixed pine/oak forests, and eventually into the climax deciduous forest dominated by oaks.

Since the Middle Ages, the lands of the catchment were used to grow cereals on terraced fields. In the first half of the twentieth century, major socio-economic changes in Spain promoted widespread migration from rural to urban areas, which lead to a total and rapid abandonment of the land which is now only partially used for grazing. The vegetation on the SWS slope is scarce and composed by sub-Mediterranean shrubs. In a clear contrast, on the NEF slope there is a dense vegetation of pines and other deciduous trees. The recovery of the natural vegetation was very rapid on the old terraced fields on the NEF slope, but much slower on the SWS slope (G. Montserrat 1990, unpublished data).

A soil survey was carried out to identify the main soil types. After field prospection, an initial mapping of the main soil units was made. The cartographic work to define the limits of the soil units used colour aerial ortophotos at a 1:18,000 scale. The soil mapping was contrasted with the analytical data of main soil properties and a final map was produced at a 1:5,000 scale. A vector-based computer aided design package (AutoCAD) was used to digitize the data of soil types. MicroStation software (I/GEOVEC) was used for the geographic vectorization of map features. Output images were processed using CorelDraw. The semidetailed scale of the soil study was used to determine the size of the soil sampling grid. Sampling points were spaced $200 \mathrm{~m}$ apart, resulting in one soil sample collected every four has approximately. The size of the grid was considered appropriate for the collection of representative soil samples because of the lithological homogeneity of the study area. Seventy-seven bulk soil cores were collected at the intersections of the $200 \times 200 \mathrm{~m}^{2}$ grid (Fig. 1).

Samples were collected using a $7.5 \mathrm{~cm}$ diameter hand-operated corer till a depth of $20 \mathrm{~cm}$. Before they were analysed, soil samples were air-dried, grinded, homogenized, quartered and passed through a $2 \mathrm{~mm}$ sieve. Total organic carbon (TOC) and nitrogen, available 
phosphorus and potassium, electrical conductivity (EC), $\mathrm{pH}$, carbonates and cation exchange capacity (CEC) were measured following standard techniques. The $\mathrm{pH}$ (1:2.5 soil : water) was measured using a $\mathrm{pH}$ metre, and $\mathrm{EC}$ (1:5 soil : water) was measured using a conductivity metre. Carbonates were measured using a Barahona calcimeter (CSIC 1976). TOC was determined by titration by the Sanerlandt Method (Guitian and Carballas 1976). Total $\mathrm{N}$ was measured using the Kjeldhal Method. Available K was extracted with ammonium acetate (Page et al. 1982) and analyses were performed by atomic emission spectrometry using a solid-state inductively coupled plasma ICP-OES. Available P was extracted with a solution of $\mathrm{CaCO}_{3}$ and $\mathrm{MgCO}_{3}$, acetic acid, and sulphuric acid, and analysed by colorimetry (CSIC 1976). To determine the exchangeable capacity by sodium displacement, a $\mathrm{Mg}\left(\mathrm{NO}_{3}\right)_{2}$ solution was used (Page et al. 1982) followed by ICP-OES analysis.

For assessing water in soil, the water retention was determined at -33 and $-1500 \mathrm{kPa}$ using a Richards Membrane. The percentages of available water and the gravimetric water content were estimated. The infiltration rate was measured using a double-ring infiltrometer at 19 sites that were representative of the main soil types in the catchment.

A map of land use in three classes (forest, shrub and pasture) was produced using colour ortophotographs that had a resolution of $0.38 \times 0.38 \mathrm{~m}^{2}$ cell size, which were obtained from the SigPac web site (http://sigpac.mapa.es) of the Spanish Ministry of Agriculture. Once the main vegetation covers were identified, an input layer was created with the polygons for the three classes distinguished and the areas of the polygons were calculated using ArcView GIS 3.2.

A raster geographical information system (Idrisi 32) was used to integrate the data base and to overlay the information. To assess the spatial distribution of the physico-chemical soil properties Surfer (win 32) Version 6.04 software was used. Two-dimensional ordinary block kriging with a linear variogram model was used to generate regular grids that had a resolution of $10 \times 10 \mathrm{~m}^{2}$. Maps of the isolevels of the soil properties were derived to represent their spatial patterns and variability within the catchment.

The Kruskal-Wallis test, a non-parametric counterpart of a one-way analysis of variance, was used to determine the fixed effect of the physiographic location of the sample points on the soil properties. For that purpose, the data points were divided into NEF and SWS location, and a confidence level of $\alpha=0.05$ was set. The correlation matrix was also obtained to determine relationships between the various soil parameters. The analyses were carried out using $R$ and Statgraphics for Windows softwares.

\section{Results and discussion}

\section{The distribution of the vegetation cover in the catchment}

The vegetation of the two parts of the catchment is clearly differentiated. On the SWS slope there are sub-Mediterranean shrubs and some bare soil that forms an open forest of lowgrowing woody plants known as "matorral". On the NEF slope there is a dense vegetation of pine and other deciduous trees. Scrubland (66\%) and forest of pine and deciduous trees $(29 \%)$ cover most of the catchment, with only $5 \%$ used as pastures (Fig. 1). 
Since the abandonment of cultivations during the first half of the twentieth century a process of natural vegetation recovery has taken place. There is a marked contrast between the two sides of the catchment with respect to this process. On the NEF slope scrubland represents $56 \%$ of the total surface, and the forest cover (36\%) is almost three times higher that on the SWS slope. Forest occupies $14 \%$ of the surface at the SWS slope, whereas scrubland reaches $82 \%$. Both areas present a similar proportion of meadows, which cover $5 \%$ of the surface.

At the divide of the catchment, some areas still have relict patches of the original vegetation of mixed oak and pine forest. Those locations are very fertile, especially a forest site at the divide of the SWS slope which differs strongly from the actual scarce vegetation cover of shrubs characteristic of the SWS slope. Such a contrast highlights the differences between the dense original vegetation that existed before the deforestation of the catchment and the actual open "matorral" formations.

\section{$\underline{\text { Soil condition in the catchment }}$}

On both sides of the Arnás River the EC of the soils was low, with significant differences between both slopes $(p=0.038)$. The highest CE values $\left(0.69 \mathrm{~d} \mathrm{Sm}^{-1}\right)$ corresponded to the NEF slope (Table 1). On average, soils were alkaline and $\mathrm{pH}$ values differed significantly between the two slopes $(p=0.007)$. The only slightly acidic soils were at the NEF slope because carbonates are almost completely leached in Lithic Hapludolls profiles. In parallel with the $\mathrm{pH}$ distribution, average carbonate content differed significantly between the two parts of the catchment $(p<0.001)$. The lowest values occurred in the soils at the NEF slope, with a minimum of $0.11 \%$ in Lithic Hapludolls. The CEC differed significantly between the two parts of the catchment $(p=0.003)$, with the highest average values $\left(20 \mathrm{cmol} \mathrm{kg}{ }^{-1}\right)$ occurring in soils at the NEF slope. Those values were expected because the soil mineralogy was dominated by clay contents between 27 and 41\% (Pardini et al. 1991). The clay types were illite-mica, chlorite, kaolinite and smectite; thus, the presence of swelling clays increases the specific surface area. The CEC values were within the interval for those mineral components and fall within the suitable range of soil fertility (Porta et al. 2003). Available phosphorous and potassium contents were highest in soils at the NEF slope, in which the maximum values were also found, although the difference was only significant for phosphorous $(p=0.040)$. In general, the average nitrogen content was low, and significantly highest at the NEF slope $(p=0.018)$ in which the maximum values were also found. The average TOC values were also significantly higher in soils at the NEF slope $(p=0.033)$, although the variability was highest in the SWS slope in which both the minimum and the maximum values occurred. The maximum values of TOC and $\mathrm{N}$ occurred in a Lithic Ustochrept site located at the divide of the catchment where a relict patch of the dense original vegetation still remains.

Table 1 Summary statistics of the chemical properties of the soils at the northeast-facing forest slope (NEF) and at the southwest-facing shrub slope (SWS) of the Arnás River catchment, Central Pyrenees, Spain

\begin{tabular}{|c|c|c|c|c|c|c|c|c|}
\hline & $\begin{array}{l}\mathrm{EC} \\
\left(\mathrm{d} \mathrm{Sm} \mathrm{Sm}^{-1}\right)\end{array}$ & pH & $\begin{array}{l}\text { Carbonates } \\
(\%)\end{array}$ & $\begin{array}{l}\text { CEC } \\
\left(\mathrm{cmol} \mathrm{kg}^{-1}\right)\end{array}$ & $\begin{array}{l}\text { TOC } \\
(\%)\end{array}$ & $\begin{array}{l}N \\
(\%)\end{array}$ & $\begin{array}{l}\text { Available P } \\
(\mathrm{mg} / 100 \mathrm{~g})\end{array}$ & $\begin{array}{l}\text { Available K } \\
(\mathrm{mg} / 100 \mathrm{~g})\end{array}$ \\
\hline \multicolumn{9}{|c|}{ NEF } \\
\hline$n$ & 48 & 48 & 48 & 48 & 48 & 48 & 48 & 48 \\
\hline
\end{tabular}




\begin{tabular}{|c|c|c|c|c|c|c|c|c|}
\hline & $\begin{array}{l}E C \\
\left(d S^{-1}\right)\end{array}$ & $\mathrm{pH}$ & $\begin{array}{l}\text { Carbonates } \\
(\%)\end{array}$ & $\begin{array}{l}\text { CEC } \\
\left(\mathrm{cmol} \mathrm{kg}^{-1}\right)\end{array}$ & $\begin{array}{l}\text { TOC } \\
(\%)\end{array}$ & $\begin{array}{l}N \\
(\%)\end{array}$ & $\begin{array}{l}\text { Available P } \\
(\mathrm{mg} / 100 \mathrm{~g})\end{array}$ & $\begin{array}{l}\text { Available K } \\
(\mathrm{mg} / 100 \mathrm{~g})\end{array}$ \\
\hline Average & 0.233 & 7.97 & 19.4 & 19.5 & 3.4 & 0.31 & 1.36 & 23.1 \\
\hline $\begin{array}{l}\text { Standard } \\
\text { deviation }\end{array}$ & 0.100 & 0.41 & 14.1 & 13.7 & 1.1 & 0.08 & 0.96 & 12.9 \\
\hline Minimum & 0.139 & 6.36 & 0.1 & 15.3 & 1.3 & 0.15 & bdl & 5.0 \\
\hline Maximum & 0.690 & 8.55 & 51.0 & 22.9 & 6.1 & 0.51 & 6.50 & 85.0 \\
\hline $\begin{array}{l}\text { Coefficient of } \\
\text { variation }\end{array}$ & 43 & 5 & 73 & 7 & 33 & 27 & 71 & 56 \\
\hline \multicolumn{9}{|l|}{ SWS } \\
\hline$n$ & 29 & 29 & 29 & 29 & 29 & 29 & 29 & 29 \\
\hline Average & 0.197 & 8.17 & 31.6 & 18.7 & 3.1 & 0.28 & 1.05 & 20.4 \\
\hline $\begin{array}{l}\text { Standard } \\
\text { deviation }\end{array}$ & 0.046 & 0.24 & 10.8 & 1.9 & 1.8 & 0.12 & 0.75 & 7.8 \\
\hline Minimum & 0.130 & 7.43 & 1.0 & 16.4 & 0.9 & 0.12 & 0.10 & 11.0 \\
\hline Maximum & 0.336 & 8.54 & 47.5 & 23.3 & 8.7 & 0.67 & 3.12 & 40.0 \\
\hline $\begin{array}{l}\text { Coefficient of } \\
\text { variation }\end{array}$ & 23 & 3 & 34 & 10 & 58 & 44 & 72 & 38 \\
\hline
\end{tabular}

The percentages of water retained at -33 and $-1,500 \mathrm{kPa}$ were lower in the soils at the SWS slope $(p<0.001)$, which also had the minimum values. The maximum water retention value was found on the relict forest site. The average infiltration rate was also lower in the SWS slope. In contrast, the NEF slope presented the maximum infiltration rates, but also a very high variability due to the larger diversity in soil types as well as in the distribution and type of vegetation. This high variability, together with a reduced number of observations for this variable, resulted in non-significant test results. However, other studies in the same area have shown a higher infiltration rate in Lithic Hapludolls and Calcic Haploxerolls, which predominate at the NEF slope (Navas et al. 2005b) (Table 2).

Table 2 Summary statistics of the physical properties of the soils at the northeast-facing forest slope (NEF) and at the southwest-facing shrub slope (SWS) of the Arnás River catchment, Central Pyrenees, Spain

\begin{tabular}{|c|c|c|c|c|}
\hline \multirow[b]{2}{*}{ NEF } & \multirow[t]{2}{*}{ Infiltration rate $\left(\mathrm{md}^{-1}\right)$} & \multicolumn{2}{|c|}{ Water retention (\%) } & \multirow[t]{2}{*}{ Available water (\% } \\
\hline & & & & \\
\hline$n$ & 13 & 48 & 48 & 48 \\
\hline Average & 0.53 & 33.9 & 22.1 & 11.8 \\
\hline Standard deviation & 0.50 & 5.3 & 5.4 & 2.3 \\
\hline Minimum & 0.13 & 23.3 & 11.0 & 6.7 \\
\hline Maximum & 1.50 & 46.8 & 40.2 & 17.2 \\
\hline Coefficient of variation & 95 & 16 & 24 & 19 \\
\hline \multicolumn{5}{|c|}{ SWS } \\
\hline$n$ & 6 & 29 & 29 & 29 \\
\hline
\end{tabular}




\begin{tabular}{|c|c|c|c|c|}
\hline & Infiltration rate $\left(\mathrm{md}^{-1}\right)$ & $\begin{array}{l}\text { Water re } \\
-33 \mathrm{kPa}\end{array}$ & $\begin{array}{l}\text { etention (\%) } \\
-1,500 \mathrm{kPa}\end{array}$ & Available water (\%) \\
\hline Average & 0.44 & 30.7 & 18.8 & 12.0 \\
\hline Standard deviation & 0.23 & 6.3 & 6.3 & 2.2 \\
\hline Minimum & 0.20 & 22.1 & 12.3 & 8.5 \\
\hline Maximum & 0.92 & 45.5 & 36.9 & 17.1 \\
\hline Coefficient of variatic & & 21 & 33 & 19 \\
\hline
\end{tabular}

The available $\mathrm{P}$ and $\mathrm{K}$ were highly positively correlated with $\mathrm{EC}$ (Table 3). As expected, $\mathrm{pH}$ and carbonates were positively correlated and both properties were negatively correlated with TOC and $\mathrm{N}$. In addition, $\mathrm{pH}$ and carbonates tended to be negatively related with available $\mathrm{P}$ and $\mathrm{K}$, although the correlations were not significant. The lowest $\mathrm{pH}(6-6.5)$ and carbonate content occurred in Lithic Hapludolls at the NEF slope, as well as the highest nutrient content. Therefore, these soils are expected to function better because the maximum availability of nutrients occurs within these $\mathrm{pH}$ ranges (Porta et al. 2003).

Table 3 Pearson correlation coefficients of the chemical properties of the soils in the Arnás River catchment, Central Pyrenees, Spain

\begin{tabular}{|c|c|c|c|c|c|c|c|c|}
\hline & $\begin{array}{l}\mathrm{EC} \\
\left(\mathrm{d} \mathrm{Sm} \mathrm{m}^{-1}\right)\end{array}$ & pH & $\begin{array}{l}\text { Carbonates } \\
(\%)\end{array}$ & $\begin{array}{l}\text { CEC } \\
\left.(\mathrm{cmol} \mathrm{kg})^{-1}\right)\end{array}$ & $\begin{array}{l}\text { TOC } \\
(\%)\end{array}$ & N (\%) & $\begin{array}{l}\text { Available } \\
\text { P (\%) }\end{array}$ & $\begin{array}{l}\text { Available } \\
\text { K (\%) }\end{array}$ \\
\hline EC & 1 & & & & & & & \\
\hline $\mathrm{pH}$ & -0.550 & 1 & & & & & & \\
\hline Carbonates & -0.293 & 0.602 & 1 & & & & & \\
\hline CEC & 0.310 & -0.443 & -0.629 & 1 & & & & \\
\hline TOC & 0.433 & $\mid-0.577$ & -0.525 & 0.772 & 1 & & & \\
\hline $\mathrm{N}$ & 0.437 & -0.604 & -0.519 & 0.754 & 0.883 & 1 & & \\
\hline $\mathrm{P}$ available & 0.732 & -0.360 & -0.242 & 0.406 & 0.455 & 0.531 & 1 & \\
\hline K available & 0.722 & $\mid-0.416$ & -0.336 & 0.171 & 0.262 & 0.323 & 0.634 & 1 \\
\hline
\end{tabular}

The CEC was positively correlated with both TOC and N, which indicates that a better nutrient status is associated with a high rate of exchange capacity. That is further confirmed by the highly positive correlations existing between CEC and TOC, N, available P and available K in soils at the NEF slope. In contrast, in the soils at the SWS slope, CEC and TOC were less strongly correlated. Regarding the associations among the soil nutrients, in general, TOC and $\mathrm{N}$ were strongly positively correlated. In addition, $\mathrm{N}$ and available $\mathrm{P}$, and available $\mathrm{P}$ and available $\mathrm{K}$ were positively correlated.

The strong negative correlations between water retention at -33 and $-1,500 \mathrm{kPa}$ and both $\mathrm{pH}$ and carbonate content indicates that higher water retention occurred in soils that had low $\mathrm{pH}$ and carbonate content, which are Lithic Hapludolls at the NEF slope (Table 4). However, the strong positive correlations between water retention at -33 and $-1,500 \mathrm{kPa}$ and CEC, TOC and N indicate that the best nutrient conditions are associated with higher water retention and hence water availability. 
Table 4 Pearson correlation coefficients of the physical and chemical properties of the soils in the Arnás River catchment, Central Pyrenees, Spain

\begin{tabular}{|c|c|c|c|c|c|c|c|c|}
\hline & $\begin{array}{l}\text { EC } \\
\left(\mathrm{d} \mathrm{Sm}^{-1}\right)\end{array}$ & $\mathrm{pH}$ & $\begin{array}{l}\text { Carbonates } \\
(\%)\end{array}$ & $\begin{array}{l}\text { CEC } \\
\left(\mathrm{cmol} \mathrm{kg}^{-1}\right)\end{array}$ & $\begin{array}{l}\text { TOC } \\
(\%)\end{array}$ & N (\%) & $\begin{array}{l}\text { Available } \\
\text { P (\%) }\end{array}$ & $\begin{array}{l}\text { Available } \\
\text { K (\%) }\end{array}$ \\
\hline $\begin{array}{l}\text { Water } \\
\text { retention } \\
-33 \mathrm{kPa}(\%)\end{array}$ & 0.484 & -0.686 & -0.627 & 0.755 & 0.891 & 0.831 & 0.427 & 0.279 \\
\hline $\begin{array}{l}\text { Water } \\
\text { retention } \\
-1,500 \mathrm{kPa} \\
(\%)\end{array}$ & 0.505 & -0.732 & -0.677 & 0.807 & 0.885 & 0.876 & 0.462 & 0.315 \\
\hline $\begin{array}{l}\text { Available } \\
\text { water (\%) }\end{array}$ & -0.060 & 0.131 & 0.140 & -0.150 & 0.001 & -0.131 & -0.099 & -0.098 \\
\hline $\begin{array}{l}\text { Infiltration rate } \\
\left(\mathrm{md}^{-1}\right)\end{array}$ & 0.341 & -0.127 & 0.033 & 0.069 & 0.143 & 0.197 & -0.101 & -0.243 \\
\hline
\end{tabular}

Spatial distribution of soil properties

According to the interpolated distribution of the chemical soil properties (Fig. 2), there is a large variation across the catchment. In most of the area, EC values were between 0.1 and $0.3 \mathrm{~d} \mathrm{Sm}^{-1}$. The spatial distribution did not show any relationship with the different soil types on both sides of the catchment, apart from the maximum values found in Lithic Hapludolls at the divide site and at the catchment outlet. $\mathrm{pH}$ values varied little throughout the catchment, and most values were between 8.0 and 8.5 . The lowest $\mathrm{pH}$ values (6.0-6.5) occurred in Lithic Hapludolls and, based on the criteria of USDA (1971), the main effect expected in soils that fall within this $\mathrm{pH}$ range is the maximum availability of nutrients.

The distribution of the carbonate content varied greatly among both sides of the Arnás catchment. The predominant values in soils at the NEF were below $30 \%$. Seventeen per cent of the area (47 ha) had values below $10 \%$, coinciding with the lowest $\mathrm{pH}$ values and the spatial distribution of Lithic Hapludolls. Since the parent materials that were common to all the soils in the catchment were rich in carbonates, the low values found in Lithic Hapludolls are likely due to their leaching downward in the soil profile (Navas et al. 2002). The occurrence of three maxima in soils at the SWS slope and at the head of the catchment confirms the abundance of carbonates in Lithic Ustochrepts and Lithic Xerorthents, which are shallow soils in which the rich carbonatic parent material predominates. However, very lowcarbonate content was also found in the SWS slope coinciding with high values of nutrients and CEC on a Lithic Ustochrept site on which a dense relict vegetation cover favours the lixiviation processes.

The CEC showed a large variability. The lowest isolevels appeared associated with Lithic Ustochrepts and Lithic Xerorthents at the SWS slope. The maximum CEC values coincided with the highest values of the nutrients (TOC, N). Furthermore, the areas that had the highest CEC also showed the lowest levels of carbonates. The CEC is influenced by mineral composition, proportions and types of clays, and the amount of organic matter (Porta et al. 
2003). In the catchment, mineral composition was fairly homogeneous; thus, variation in CEC was mainly related with the variation in organic matter.

The spatial distribution of TOC shows the highest values (between 4 and $6 \%$ ) associated to Lithic Hapludolls, as it was expected because there is more organic matter under the forest. These more organic-rich soils are better developed and structured and have a higher infiltration rate. In addition, the areas of dense vegetation have higher root densities that also contribute to improve water circulation and facilitate the leaching of soil constituents. A previous study on the transfer of chemical elements showed a highest mobility and leaching of carbonates in soils with similar characteristics (Navas et al. 2005b). This can be explained by a more stable soil situation under forest (almost no erosion) and the fact that more organic acids exist due to an incomplete oxidation of organic matter that increase carbonate leaching. The areas with the lowest TOC were most abundant in Lithic Xerorthents at the SWS slope.

The spatial distribution of total nitrogen paralleled that of TOC; thus, the largest area of highnitrogen level was at the NEF, especially in Lithic Hapludolls. The lowest $\mathrm{N}$ levels, on the contrary, occurred in Lithic Xerorthents at the SWS slope.

The available potassium varied little in the catchment, which might be due to the abundance of K-rich minerals in the parent materials from which the different soil types are derived (Pardini et al. 1991).

Throughout most of the catchment, the available phosphorous ranged between 1 and $2 \mathrm{mg} / 100 \mathrm{~g}$. The largest area of low values was located in soils at the SWS slope. At the NEF slope, the area with low values occurred in soils that surround a gully. Furthermore, the maximum values of available $\mathrm{P}$ and $\mathrm{K}$ were found at a pasture site that is fertilized occasionally.

The highest values of water retention at -33 and $-1,500 \mathrm{kPa}$ occurred in Lithic Hapludolls. The water content and retention of the soils were significantly higher at the NEF slope than they were at the SWS slope (Fig. 3). As much as $73 \%$ of the surface area at the NEF slope had values of water retention at $-33 \mathrm{kPa}$ of $30-40 \%$, whereas in a similar percentage of the surface area at the SWS slope the range of water retention values was smaller $(25-35 \%)$ (Fig. 4). Over almost half (45\%) of the surface area at the NEF slope, water retention at $-1,500 \mathrm{kPa}$ was $20-25 \%$, whereas, in most of the SWS slope $(57 \%)$, the range was lower (15-20\%). About $60 \%$ of the NEF slope had water contents between $10-20 \%$, whereas at the SWS slope almost the same percentage area had lower values (0-10\%).

A large area of the SWS slope (20\%) had a low-infiltration rate $\left(<0.25 \mathrm{md}^{-1}\right), 63 \%$ ranged between 0.25 and $0.50 \mathrm{md}^{-1}$, and no values above $1 \mathrm{md}^{-1}$ existed. On the contrary, in most of the NEF slope ( $72 \%$ of the area) the infiltration rates were between 0.5 and $1 \mathrm{md}^{-1}$, and $10 \%$ of the area had values above $1 \mathrm{md}^{-1}$ (Fig. 4).

The spatial distribution of the physical properties indicate that the soils at the NEF slope had better water retention and more water available for the growth of vegetation. In addition, the water infiltration rate was higher in the soils at the NEF slope than in the soils at the SWS slope. Daily et al. (1997) emphasized the importance of the transport and retention of water in maintaining soil functions, such as the transport and cycling of nutrients, which are of importance for the maintenance of the ecosystems. In the soils at the NEF slope water 
penetrates deeper in the soil profile, particularly in Lithic Hapludolls as reflected by the degree of carbonate leaching, which contributes to better cycling of nutrients. Furthermore, the highest water retention ( -33 and $-1,500 \mathrm{kPa}$ ) and available water at the NEF slope influence positively the ability of soils to support vegetation.

On the other hand, the shaded orientation of the NEF slope reduces water evaporation. Although the proportion of rainfall intercepted by the more dense vegetation cover should be higher in that part of the catchment than elsewhere, the combination of factors above mentioned suggest that the water cycle best suits the development of vegetation in soils at the NEF slope. This is consistent with the distribution of the natural vegetation cover that appears after land abandonment. Furthermore, soils under dense vegetation maintain the moisture content better than less vegetated areas that have higher solar radiation, surface temperature and evaporation. At present, most of the catchment is rangeland, and the forested area at the NEF slope is more than three times larger than at the SWS slope (Fig. 1).

The maps of land use and physico-chemical properties of the soils illustrate the close correspondence between the location of the largest forest area within the catchment and the soils that have the highest water retention, moisture contents and infiltration rates. In addition, the forest has the highest levels of CEC and soil nutrients, especially TOC and total nitrogen, and higher levels of available $\mathrm{P}$ and $\mathrm{K}$. The forest, which is at the lower reach of the catchment on its north side (NEF slope), has grown mainly on Lithic Hapludolls and Calcic Haploxerolls that are the best structured and well-developed soils in the catchment.

It appears that differential soil erosion after land abandonment, which was much more severe on the steeper slopes at the SWS slope than at the NEF slope, was a key factor in the impoverishment of the soil and the increase in the differences in soil quality between the two parts of the catchment. In the study area, erosion rates were estimated using fallout ${ }^{137} \mathrm{Cs}$ (Navas et al. 2005a). On the SWS slope the highest erosion rates $\left(30 \mathrm{t} \mathrm{ha}^{-1}\right.$ year $\left.^{-1}\right)$ were measured at upslope locations, and lower soil losses ( $12 \mathrm{t} \mathrm{ha}^{-1}$ year $^{-1}$ ) were registered at downslope sites. In contrast, on the NEF slope soil stability and deposition $\left(<1 \mathrm{t} \mathrm{ha}^{-1}\right.$ year $\left.^{-1}\right)$ were predominant.

In the process of vegetation recovery, grasses dominate during about 15 years after land abandonment until the shrubs cover progresses and pine trees start to colonize the shadow areas close to pre-existing forest patches (Molinillo et al. 1997). After a prolonged and not well determined period the pine trees are progressively replaced by deciduous species such as $Q$. faginea. In a large portion of the NEF slope that succession stage has been reached already, and we associate this to a best function of Lithic Hapludolls and Calcic Haploxerolls. At the SWS slope, the vegetation succession is at an earlier stage because of the relatively poor condition of Lithic Ustochrepts and Lithic Xerorthents. Land abandonment has had a stronger impact on the latter soils.

The increased erosion after land abandonment is due to a combination of factors. First, the lands were in general abandoned after the harvest, the soil surface being left bare just at the time when storm events are more frequent and intense. The absence of land plough after the harvest and the rain splash contributed to the fast development of a soil crust on these bare surfaces. As a result, a significant increase in runoff results, which is directly related to increased erosion. Moreover, other conservation practices like terraces and stone walls are 
no longer maintained, and when these structures are destroyed it also results in increased erosion.

In addition, the poorer soils on the sunny side of the catchment limited the re-growth of vegetation compared to the better quality soils at the NEF slope. For a similar slope gradient, on the SWS slope soils are usually drier, have higher hydrophobicity and are more susceptible to runoff and therefore to erosion. Considering a medium term and because the differences in soil properties are great, it can be expected that the actual differences in the vegetation will last for a long time. It is probable that the fully recovery of the vegetation on the SWS slope will take much longer than on the NEF slope.

\section{Conclusions}

In the Arnás River catchment, Calcic Haploxerolls and Lithic Hapludolls on the NE-orientated slopes (NEF) had better nutrient status and higher water retention and water circulation. These characteristics determine their better function in comparison with Lithic Ustochrepts and Lithic Xerorthents on the SW-orientated slopes (SWS). In this part of the catchment the sunny orientation, steepest slope and the existence of poorly developed and shallow soils that are impoverished in nutrients as result of highest erosion rates, make the vegetation regrowth much more difficult.

The agrarian policy of the European Union encourages the abandonment of marginal and less productive lands. Our study and others have demonstrated that care should be taken when lands are abandoned. Since the soils and vegetation cover are similar over a vast area of the Central Spanish Pyrenees, we expect that other south and southwest-facing slopes in mountainous areas within the temperate Mediterranean region will have poor soil function compared to soils on north-facing slopes.

The natural re-growth of forests on abandoned lands is a good means of minimizing desertification by increasing the amount of soil surface protected from erosion, and it allows for an increase in biodiversity and environmental sustainability. However, right after the abandonment of the cultivation practices, a period of intense erosion is usually observed which reduces the soil quality. Therefore, before land is abandoned, we recommend that the soil surface be protected against further erosion by planting grass that can cover the soil until the land is colonized by shrubs through natural succession processes.

Acknowledgements We thank the EEC project (EN AA 123431. PL. 1995-1999) and CICYT projects RADIERO (REN2002-02702/GLO) and REM (CGL2005-02009/BTE) for financial support. The comments provided by $\mathrm{M}$. Egli and another anonymous reviewer are gratefully acknowledged.

\section{References}

Beguería S, López-Moreno JI, Lorente A et al (2003) Assessing the effect of climate oscillations and land-use changes on streamflow in the Central Spanish Pyrenees. Ambio 32(4):283-286 
Berry JK (1987) Fundamental operations in computer assisted map analysis. Int J Geogr Inf Syst 1:119-136

Burger JA, Kelting DL (1998) Soil quality monitoring for assessing sustainable forest management. In: Davidson EA et al (eds) The contribution of soil science to the development and implementation of criteria and indicators of sustainable forest management. SSSA. Spec. Publ. 53. SSSA, Madison, WI, pp 17-52

Burrough PA (1986) Principles of geographical information systems for land resources assessment. Clarendon Press, University Press, Oxford, p 193

Carter BJ, Ciolkosz EJ (1991) Slope gradient and aspect effects on soils developed from sandstone in Pennsylvania. Geoderma 49:199-213

CSIC (1976) Comisión de métodos analíticos. An Edafol Agrobiol 35:13-814

Daily GC, Matson PA, Vitousek PM (1997) Ecosystem services supplied by soil. In: Daily GC (ed) Nature's services: societal dependence on natural ecosystems. Island Press, Washington, DC, pp 113-132

De la Rosa DJ, Crompvoets F, Mayo J et al (1996) Land vulnerability evaluation and climate change impact in Andalucia, Spain. Int Agrophys J 10:225-238

Egli M, Wernli M, Kneisel C et al (2006a) Melting glaciers and soil development in the proglacial area Morteratsch (Swiss Alps): I Soil type chronosequence. Arct Antarct Alp Res 38:499-509

Egli M, Wernli M, Kneisel C et al (2006b) Melting glaciers and soil development in the proglacial area Morteratsch (Swiss Alps): II Modelling present-day and future soil state. Arct Antarct Alp Res 38:510-522

FAO (1989) Soil map of the world. Revised legend. FAO, Rome

García-Ruiz JM, Arnáez J, Beguería S et al (2005) Runoff generation in an intensively disturbed, abandoned farmland catchment, Central Spanish Pyrenees. Catena 59:79-92

García-Ruiz JM, Lasanta T (1990) Land-use changes in the Spanish Pyrenees. Mt Res Dev 10:267-279

Guitian F, Carballas T (1976) Técnicas de análisis de suelos. Ed. Pico Sacro, Santiago de Compostela Spain, p 288

Karlen DL, Mausbach MJ, Doran JW et al (1997) Soil quality: a concept, definition, and framework for evaluation. Soil Sci Soc Am J 61:4-10

Lorente A, Martí Bono C, Beguería S (2000) La exportación de sedimento en suspensión en una cuenca de campos abandonados, Pirineo central español. Cuat y Geomorf 14(1-2):2134 
Lu D, Moran E, Mausel P (2002) Linking Amazonian secondary succession forest growth to soil properties. Land Degrad Dev 13:331-343

Machín J, Navas A (1995) Land evaluation and conservation of semiarid agrosystems in Zaragoza (NE Spain) using an Expert Evaluation System and GIS. Land Degrad Rehabil 6:203-214

Molinillo M, Lasanta T, García-Ruiz JM (1997) Managing mountainous degraded landscapes after farmland abandonment in the Central Spanish Pyrenees. Environ Manage 21:587-598

Navas A, García-Ruiz JM, Machín J (1997) Aspects of soil erosion in dry farming land in two changing environments of the central Ebro valley, Spain. In: Walling DE, Probst JL (eds) Human impact on erosion and sedimentation. IAHS 245, Wallingford, pp 13-20

Navas A, Soto J, Machín J (2002) ${ }^{238} \mathrm{U},{ }^{226} \mathrm{Ra},{ }^{210} \mathrm{~Pb},{ }^{232} \mathrm{Th}$ and ${ }^{40} \mathrm{~K}$ activities in soil profiles of the Flysch sector (Central Spanish Pyrenees). Appl Radiat Isotopes 57:579-589

Navas A, Machín J, Soto J (2005a) Assessing soil erosion in a Pyrenean mountain catchment using GIS and fallout ${ }^{137}$ Cs. Agric, Ecosyst Environ 105:493-506

Navas A, Soto J, Machín J (2005b) Mobility of natural radionuclide and selected major and trace elements along a soil toposequence in the Central Spanish Pyrenees. Soil Sci 170(9):743-757

Page AL, Mille RH, Keeney DR (1982) Methods of soil analysis. Part 2. Chemical and microbiological properties. American Society of Agronomy, 2nd edn. Soil Science Society of America, Madison, Wisconsin, pp 1159

Pardini G, Aringhieri R, Plana F (1991) Soil properties relevant to land degradation in abandoned sloping fields in Aisa valley, Central Pyrenees (Spain). Pirineos 137:79-93

Porta J, López Acebedo M, Roquero C (2003) Edafología para la agricultura y el medio ambiente, 1st edn. Ediciones Mundi-Prensa, Madrid, pp 929

Rogowski AS (1996) Quantifying soil variability in GIS applications: II. Spatial distribution of soil properties. Int J Geogr Inf Syst 10:455-475

Sanchez-Marañón M, Soriano M, Delgado G et al (2002) Soil quality in Mediterranean mountain environments: effects of land use change. Soil Sci Soc Am J 66:948-958

Seybold CA, Herryck JE, Brejda JJ (1999) Soil resilience, a fundamental component of soil quality. Soil Sci 164:224-234

Sparling GP, Hart PBS, August JA et al (1994) A comparison of soil and microbial carbon, nitrogen and phosphorus contents, and macro aggregate stability of a soil under native forest and after clearance for pastures and plantation forest. Biol Fertil Soil 17:91-100

USDA (1971) Guide for interpreting engineering uses of soils. Soil Conservation Service, U.S. Government Printing Office, Washington, D.C. 
Vicente Serrano SM, Lasanta T, Cuadrat JM (2000) Transformacciones en el paisaje del Pirineo como consecuencia del abandono de las actividades económicas tradicionales.

Pirineos 155:111-133

Villar L, Sesé JA, Ferrández JV (2001) Atlas de la Flora del Pirineo aragonés. II, Instituto de Estudios Altoaragoneses y Consejo de Protección de la Naturaleza de Aragón, Huesca, Zaragoza, p 790

Webb KT, Wang C, Astatkie T et al (2000) Spatial and temporal trends in soil properties at a soil quality benchmark site in Central Nova-Scotia. Can J Soil Sci 80:567-575 
Fig. 1 The location of the study area in the Borau Valley, Central Pyrenees, Spain. Soil types, vegetation cover, slope, aspect and location of sampling grid points in the Arnás River catchment
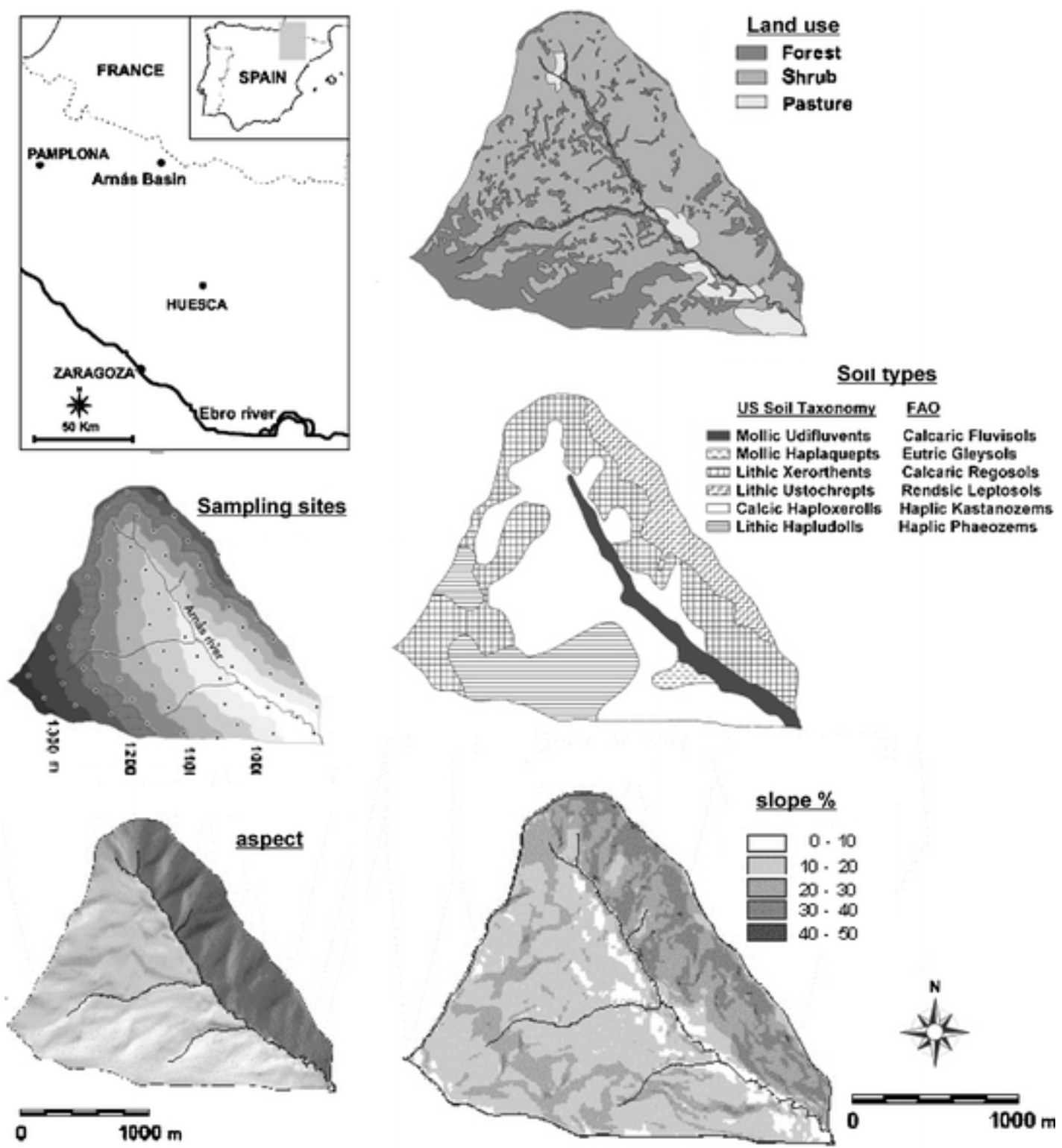
Fig. 2 Spatial distributions of the main chemical soil properties in the Arnás River catchment, Central Pyrenees, Spain
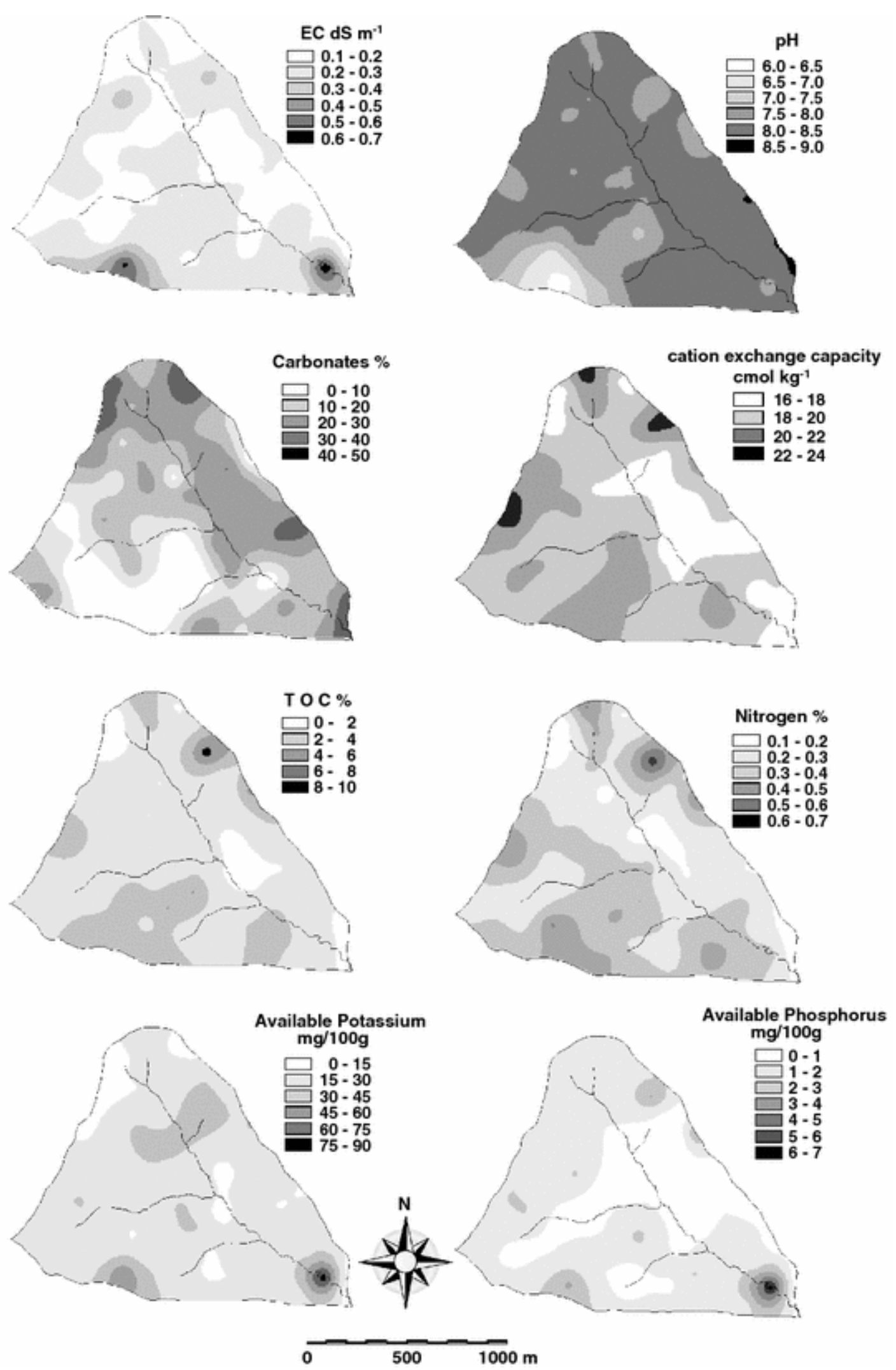
Fig. 3 Box-and-whisker plots of water retention, water content, and infiltration rates of the soils at the northeast-facing forest slope (NEF) and at the southwest-facing shrub slope (SWS) of the Arnás River catchment, Central Pyrenees, Spain. The lower boundary of the box is the 25th percentile, the upper boundary is the 75th percentile, the line inside the box is the 50th percentile, the mean is plotted as a point, the median is a small line
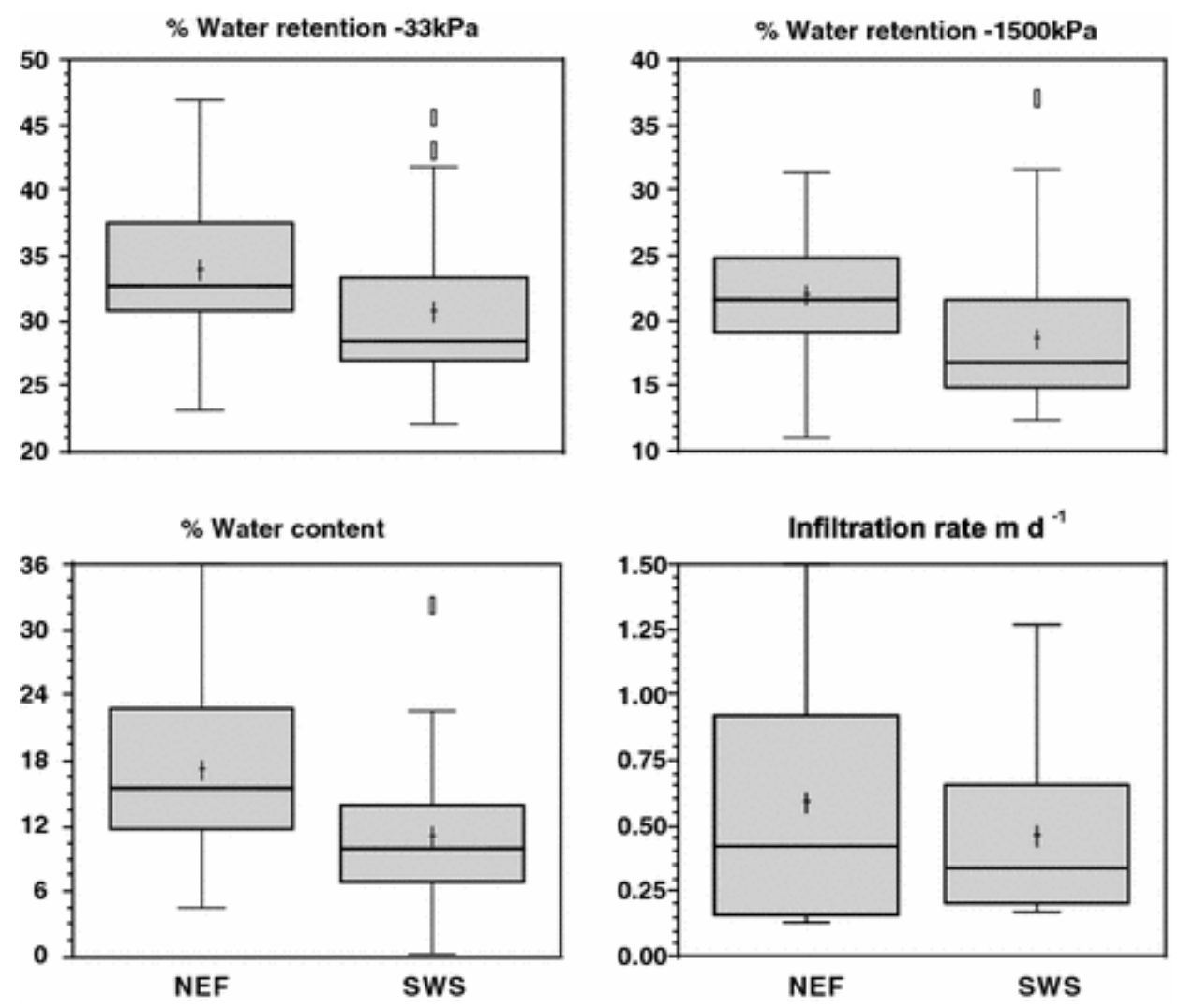
Fig. 4 Spatial distribution of water retention, water content and infiltration rates of the soils of the Arnás River catchment, Central Pyrenees, Spain
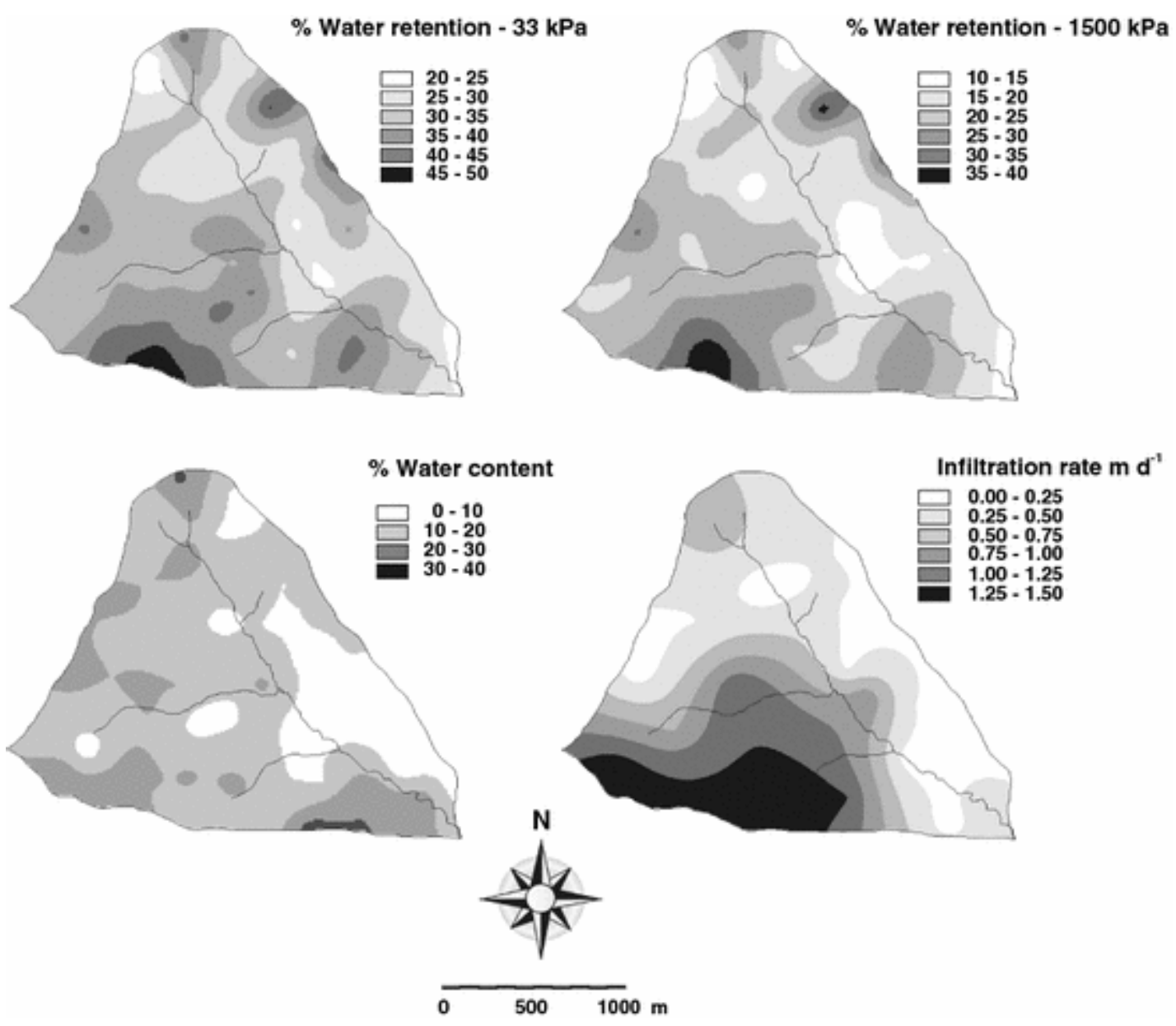